\title{
Beyond Posted Prices: The Past, Present, and Future of Participative Pricing Mechanisms
}

\author{
Based on the Session "Beyond Posted Prices: Customer-Driven Pricing Mechanisms" \\ at the $10^{\text {th }}$ Choice Symposium, May 2016
}

Forthcoming in Customer Needs and Solutions

(Special Issue in connection with the 2016 Choice Symposium)

This version:

September 29, 2017

Martin Spann (U Munich, spann@bwl.lmu.de)

Robert Zeithammer (UCLA, robert.zeithammer@anderson.ucla.edu)

Marco Bertini (ESADE, marco.bertini@esade.edu)

Ernan Haruvy (UT Dallas, eharuvy@utdallas.edu)

Sandy D. Jap (Emory, SJAP@emory.edu)

Oded Koenigsberg (London, okoenigsberg@london.edu)

Vincent Mak (Cambridge, v.mak@jbs.cam.ac.uk)

Peter Popkowski Leszczyc (U Alberta, ppopkows@ualberta.ca)

Bernd Skiera (U Frankfurt, skiera@wiwi.uni-frankfurt.de)

Manoj Thomas (Cornell, manojthomas@cornell.edu) 


\section{Beyond Posted Prices: The Past, Present, and Future of Participative Pricing Mechanisms}

\section{Contribution Statement}

Driven by the low transaction costs and interactive nature of the internet, customer participation in the price-setting process has increased. These changes were first brought about by the rise of online auctions in the early 2000s, followed by the emergence of newer participative mechanisms. Today, platforms such as eBay have popularized online auctions on a global scale, Priceline has made headlines with its name-your-own-price (NYOP) business model, and Humble Bundle has enabled independent musicians and game developers to market their works through pay-what-youwant (PWYW) pricing. Advertising exchanges conduct several hundred million individual auctions per day to sell online advertising slots. These are just a few examples of participative pricing in transactions among consumers or businesses. In parallel, academic research on participative pricing has blossomed in recent years, with an overarching concern over the profitability and other marketing implications these mechanisms have on sellers and buyers.

The present paper contributes to this literature in three ways. First, we propose a definition of participative pricing mechanisms, as well as a useful taxonomy. Second, we discuss the current understanding by synthesizing conceptual and empirical academic literature. Third, we outline promising research questions with a key focus on the related behavioral aspects of buyers and sellers. 


\section{Introduction}

Almost 150 years since John Wanamaker introduced the first price tag to discourage haggling, buyers again have a say in the prices they pay. This resurgence of buyer participation in the pricesetting process is driven in part by the internet, where buyers and sellers can interact at little to no cost. Moreover, the falling costs of implementing a participative pricing mechanism, such as an auction, have broadened the scope of participative mechanisms from their historical niche applications to almost all mainstream consumer products such as durables and services (Pinker, Seidmann, and Vakrat 2003). The scope broadening is not limited to auctions-new pricing techniques in which the buyer takes center stage, such as name-your-own-price (NYOP) or paywhat-you-want (PWYW), have emerged, both online and in traditional brick-and-mortar retail environments (Krämer et al. 2017).

From the standpoint of a seller, the thought of introducing a pricing mechanism that grants some control to buyers rests on a thorough understanding of their likely behavior. Classical auction theory provides a starting point, but humans are known to systematically deviate from behaviors implied by standard microeconomic assumptions. Behavioral economics and consumer behavior help provide richer and more realistic theories of buyer behavior.

The goal of this review article is to provide the conceptual and empirical background from the academic literature on participative pricing, define a comprehensive taxonomy, and outline promising research questions with a special focus on realistic models of buyer behavior. In section 2 below, we suggest a definition and a taxonomy for participative pricing mechanisms. We then use the taxonomy to organize our discussion of participative pricing mechanisms in sections 3 and 4 . Section 5 discusses outcome and process utility in participative pricing as an important example of a behaviorally realistic model. Section 6 discusses industry-specific applications of 
participative pricing mechanisms in business-to-business (B2B) domains, advertising, and charity. Section 7 concludes.

\section{Background and Taxonomy}

Consider a potential trade of a product, initially owned by a seller who faces one or more buyers. For example, the product may be a baseball card a collector offers for sale in an eBay auction. Or the product may be a hotel room Priceline offers in its NYOP channel, with Priceline being the seller and a traveler playing the role of the buyer. Or the product may be a bridge-building contract a state government (the seller) offers in a procurement reverse auction, with contractors playing the roles of buyers.

We use the term participative pricing mechanisms to reflect the core idea that buyers help determine the final price of a product by means of a bid or offer. Moreover, we define a participative pricing mechanism according to the following two criteria:

I. A potential buyer submits a binding bid or an offer for a product.

II. The rules of the mechanism map each bid or offer to a probability in the interval [0\%, $100 \%$ ] that the potential buyer receives the product.

The probability range merits clarification. First, not having probabilistic acceptance, that is, accepting all offers or rejecting all offers, is included in that $[0 \%, 100 \%]$ interval. But many interesting mechanisms, including auctions, bargaining, and NYOP selling, result in probabilities of acceptance that are greater than zero but less than 1 .

We offer a taxonomy (see Table 1) to classify different participative pricing mechanisms along the following two dimensions:

1) Competition among potential buyers for the same object: whether the outcome depends on the action of other (potential) buyers. 
2) Extent of interactivity after the buyer submits the bid, where "interactive" mechanisms give the seller an active role in the outcome and "not interactive" mechanisms do not.

Table 1: Taxonomy of participative pricing mechanisms

\begin{tabular}{|c|c|c|c|}
\hline & \multicolumn{2}{|c|}{ Competition among potential buyers } \\
\hline & & No & Yes \\
\hline \multirow{2}{*}{$\begin{array}{l}\text { Interactivity } \\
\text { after } \\
\text { bidding }\end{array}$} & Interactive & $\begin{array}{l}\text { Name your own price } \\
\text { (NYOP), Bargaining }\end{array}$ & $\begin{array}{l}\text { Auctions with active seller } \\
\text { participation (e.g., a hidden } \\
\text { reserve price) }\end{array}$ \\
\hline & Not Interactive & $\begin{array}{c}\text { Pay what you want } \\
\text { (PWYW) }\end{array}$ & $\begin{array}{l}\text { Auctions without active } \\
\text { seller participation (e.g., a } \\
\text { public reserve price) }\end{array}$ \\
\hline
\end{tabular}

Following Table 1, we identify four types of participative pricing mechanisms: (1) NYOP auctions (and other forms of bargaining) in which the seller actively decides whether to accept the buyer's offer after receiving it, and the outcome for one buyer is independent of other buyers' actions (e.g., NYOP auctions for hotels at the online travel intermediary Priceline.com); (2) auctions with a seller who reserves the right to reject bids after seeing them (e.g., used-car auctions at Manheim ${ }^{1}$ or auctions for a flight upgrade such as Lufthansa's "MyOffer"2); (3) mechanisms whereby the outcome for one buyer is independent of other buyers, and the seller is passive (e.g., PWYW); and (4) auctions with a public reserve whereby the outcome depends on buyers' bids, and the seller is committed to accepting offers according to a published and deterministic algorithm (e.g., eBay auctions without a hidden reserve price set by the seller before the auction starts).

\footnotetext{
${ }^{1}$ https://www.manheim.com/publicauctions/sales.do

2 At this auction, passengers with a ticket can submit a (binding) bid for an upgrade (if available) until 72 hours prior to departure. Lufthansa informs bidders 24-36 hours prior to departure whether their bid was accepted (http://www.lufthansa.com/de/de/myOffer). Other airlines also use this mechanism (http://www.plusgrade.com).
} 
The role of competition with other buyers in the taxonomy is obvious: in mechanisms with competition, the buyers are engaged in a strategic interaction, and some concept of equilibrium is essential for modeling their behavior. The role of interactivity in the taxonomy introduces an analogous and additional level of strategic complexity to the buyer's decision making, because buyers need to form a belief about the expected behavior of the seller. Note that in both (1) and (2), the seller's involvement may be literal or facilitated by a computer algorithm, and the key buyer-side distinction of seller involvement is the increased strategic complexity of the decision and increased uncertainty about the outcome.

Bertini and Koenigsberg (2014) and Kim, Natter, and Spann (2009) suggested previous taxonomies and classifications of participative pricing mechanisms. Our goal is to focus on the common and differentiating elements of these mechanisms, in particular, the behavioral issues inherent in employing each. We start with a discussion of the mechanisms in the order they are shown in Table 1.

\section{Participative Pricing without Buyer Competition: NYOP, Bargaining, and PWYW}

We briefly review previous research on participative pricing mechanisms without competition among buyers. As Table 1 indicates, NYOP, bargaining, and PWYW all fall within this category. Under these mechanisms, a single buyer generates and submits a price or an offer for a product, and the buyer's chances of receiving the product do not depend on the actions of other buyers, if any. Under NYOP and bargaining, the seller has some final control over the transaction via the right to accept or reject the transaction upon receiving the buyer's submitted price; hence, the submitted price is typically termed a "bid" or "offer," and the acceptance probability is typically

less than $100 \%$. By contrast, under PWYW, the transaction is unconditional, so the buyer can buy at any price of his or her choice, including zero, with a $100 \%$ acceptance probability by design. 


\subsection{Name Your Own Price}

NYOP can be seen as a reverse version of traditional posted pricing: under the traditional mechanism, the seller posts a price, which the buyer then accepts or rejects; under NYOP, the two parties swap their roles in the same sequence of actions. As Hinz, Hann, and Spann. (2011, p. 81) introduced,

In contrast to a typical retail setting, in NYOP markets, it is the buyer who places an initial offer. This offer is accepted if it is above some threshold price set by the seller. If the initial offer is rejected, the buyer can update her offer in subsequent rounds. By design, the final purchase price is opaque to the public; the price paid depends on the individual buyer's willingness-to-pay and offer strategy.

Because NYOP requires initial price generation and submission from the buyer, as well as a subsequent accept/reject response from the seller, it benefits from a transaction environment that allows efficient communication between the two sides. Therefore, unsurprisingly, the rise of the internet in the late 1990s and early 2000s led to the emergence of some prominent NYOP sellers. In fact, NYOP received widespread attention when Priceline.com pioneered it in 1997.

Research on NYOP has employed diverse methodologies, such as empirical data analysis, field and laboratory experimentation, as well as analytical economic modeling. The central research question is whether NYOP could be a more profitable pricing mechanism than traditional posted pricing - and relatedly, what kind of transaction environment and design features would be conducive to the profitability of NYOP. Shapiro's (2011) general analysis of a model that incorporates buyers' risk attitude (i.e., the impact of uncertainty on buyers) shows NYOP is often more profitable than posted price. Shapiro and Zillante's (2009) experimental study on NYOP produced similarly positive conclusions. Wang, Gal-Or, and Chatterjee (2009) obtained separate 
analytical evidence on how NYOP could improve profitability via its impact on inventory management in a channel setting in the travel industry. On the other hand, several papers find NYOP can at best match posted prices (Zeithammer 2015) or is weakly dominated by posted prices (Fay 2004, 2009). Therefore, whether NYOP outperforms posted prices is still an open research question.

A specific line of research focuses on the profitability impact of strategic buyer decisions in response to NYOP, in particular, repeated bidding, which could be seen as a form of haggling. Using analytical modeling supplemented by empirical data, Terwiesch, Savin, and Hann (2005) found evidence that an NYOP retailer could engage in online haggling to improve profits, by achieving finer market segmentation and thus price discrimination. Fay (2004) found repeated bidding could have a non-intuitive profit impact on the seller, and the seller should encourage it under some conditions. Nonetheless, previous empirical research points out online haggling could introduce substantial frictional and search costs to the transactions (Hann and Terwiesch 2003; Spann, Skiera, and Schäfers 2004).

Another direction of research focuses on optimal design under NYOP. Amaldoss and Jain (2008) showed how allowing consumers to place joint bids on multiple items could be more profitable for the seller. Hinz et al. (2011) suggested a profitable strategy for the seller is to employ an adaptive, transparent threshold, and to set a positive entry fee. Hinz and Spann (2008) pointed out that because an NYOP seller typically has a secret reserve price, information about that reserve price, which diffuses in consumers' social networks, could have a significant impact on the seller's profit.

Meanwhile, consumer behavior researchers have investigated the psychological impact of NYOP-type participative pricing mechanisms on consumers. Chernev (2003) found consumers 
could be less inclined to name a price, compared with choosing from among a list of posted prices for purchase. Spann and Tellis (2006) showed bidders partially deviate from rational bidding in NYOP auctions. Chandran and Morwitz (2005) suggested participative pricing mechanisms such as NYOP could increase the consumer's perceived control over the shopping situation. In a wider sense, these studies help us understand the impact of "process utility" on consumers under participative pricing mechanisms.

Future research on NYOP may try to gain a better understanding of the outcome and process utility of NYOP as well as why its prevalence is still limited. ${ }^{3}$ See our related section 5 below.

The optimal design of NYOP accounting for potential non-rational behavior of bidders is another promising area of research in this domain, because most papers on optimal design assume bidders are rational. One key element of NYOP auctions is the uncertainty of bid acceptance for bidders. Therefore, how bidders may deviate from rationality in their formation of beliefs about the uncertain acceptance of bids as well as their uncertainty-related preferences is unclear.

\subsection{Bargaining}

In settings such as bazaars, garage sales, flea markets, and other transaction contexts (Evans and Beltramini 1987), consumers negotiate prices. In addition, high-value products such as homes, automobiles, furniture, and appliances are commonly subject to bargaining or negotiation over prices as well as other value-added services (e.g., financing, delivery, warranty, installation). Negotiation is a complex social process involving posturing, social interactions, and consumer orientations (Evans and Beltramini 1987) that determine the bargainer's strength and success in the negotiation process.

\footnotetext{
${ }^{3}$ Priceline has a patent on this mechanism in the United States. Although this patent does not extend to Europe, trademark rights do, which may be one reason other companies are hesitant to adopt the mechanism.
} 
The bargaining literature is particularly relevant in B2B settings, such as bargaining by channel members. Biyalogorsky and Koenigsberg (2010) study a setting wherein channel members have to decide which firm will own the units until demand uncertainty is resolved. They find negotiations between the manufacturer and the retailer can lead to the first-best outcome, but only under quite restrictive constraints that include direct side payments by the retailer to the manufacturer and the retailer being pessimistic about its outside option during the negotiation.

Haruvy, Katok, and Pavlov (2016) tackle the possibility that the failure to coordinate in a channel setting is the result of bargaining-related behavioral motives. They propose and develop a behavioral model based on reciprocal concessions that explains empirical patterns in bargaining between channel members. In particular, they noted experiment participants in the role of manufacturers tend to make many offers that gradually increase retailer surplus by deliberately starting out with an inefficient offer in order to be able to make relatively costless concessions, as opposed to starting out with an efficient offer and making costly concessions. They find process modifications - such as allowing for reciprocal concessions — can drastically improve efficiency.

As the understanding of bargaining solutions grows and the literature proposes new mechanisms, new questions for future research in bargaining are emerging in two directions. First, the realization is growing that bargaining is not simply a standalone mechanism that warrants a specialized set of solutions. Rather, bargaining could be thought of as part of a process that may include the other participative pricing approaches we discuss. For example, an NYOP mechanism (section 3.1) may lead to a rejection, but that rejection may be followed up with a counteroffer or an invitation to try again (as Priceline does when it rejects an offer). Likewise, at the conclusion of an auction (section 4), a seller may approach losing bidders and offer them another item at a 
lower price. eBay formalizes this concept as a "second-chance offer." ${ }^{4}$ Similarly, an auction in a B2B setting (section 6.1) could result in more bargaining, either in the form of seeking additional concessions from the winning supplier or in squeezing competing suppliers for concessions. Such "second-chance offers" can increase bidder's propensity to enter a participative pricing mechanism as they may increase the expected chance of success in these mechanisms.

A second direction for future research questions involves a choice between bargaining formats. A critical concept in bargaining is the concept of bargaining power, which roughly translates to how advantaged a party is in the bargaining. As a simple illustration, consider Gneezy et al. (2003), who illustrate bargaining position could shift with the simple addition of a deadline. A proposer in that paper was the advantaged party until a deadline was added, which shifted the bargaining advantage to the responder. Haruvy et al. (2016) likewise showed adding the ability to respond to an offer with a counteroffer might shift the bargaining advantage from the manufacturer to the retailer. Thus, a critical avenue for future research is to address how the bargaining format is determined. If parties can bargain over the outcome, we have no reason to assume they will not bargain over the format or mechanism to determine that outcome.

\subsection{Pay What You Want}

Asking people to pay what they want (or can) to a church's collection plate, at a school fundraiser, or a public radio pledge drive is not uncommon. In fact, one of the most fundamental problems investigated in economics is the design of and behavior in voluntary contribution mechanisms (VCM), wherein people need to determine what amount to contribute to a public good, and where

\footnotetext{
${ }^{4}$ See http://pages.ebay.com/help/sell/second_chance_offer.html: "When you send a Second Chance Offer, you give the bidder the chance to buy the item at a Buy It Now price equal to their last bid amount. It's up to the buyer to decide whether to accept the offer."
} 
the dominant selfish strategy appears to be contributing nothing at all (Isaac and Walker 1988, Masclet et al. 2003, Boschet et al. 2006, Carpenter 2007).

Different from VCM, the PWYW mechanism applies to the voluntary payment for a product for private as well as public consumption, although the public-good connotation is sometimes apparent.

Examples include music busking on streets and, arguably, museums with nominally free admission but pleas for voluntary payment at the entrance. The internet, with its ability to reach out to a large potential market with ease, facilitated the spread of this pricing mechanism. For example, the British band Radiohead made headlines in 2007 by making a new album available online under PWYW (Elberse and Bergsman 2008); because music albums by established artists were traditionally sold with fixed, posted prices, Radiohead's move became a talking point and public relations stunt by virtue of its deviation from industry conventions. However, Radiohead's PWYW was not widely followed in the mainstream music industry. Rather, online PWYW has become a way by which less well-known independent music artists - in fact, creative industry aspirants in general, including game developers-could gain market exposure with some immediate revenue gain. Additionally, PWYW can be used to sell software on online platforms such as the Humble Bundle website (Bertini and Koenigsberg 2014; Chen, Koenigsberg, and Zhang, forthcoming) or for article processing charges (APCs) in (gold) open access publishing (Spann, Stich, and Schmidt, forthcoming).

Field evidence has shown PWYW indeed could generate substantial positive revenues (Kim et al. 2009, 2010). Much research has focused on the behavioral factors that could influence payments, such as perceived norms regarding fairness, altruism, and reciprocity (see Bertini and Koenigsberg [2014] and Schmidt et al. [2015]), as well as the presence of reference prices (e.g., 
Kunter 2015). Some of the striking results in this line of research are that payments could be significantly improved when consumers know that what they pay will be partially channeled to charitable causes (Gneezy et al. 2010) or could foster their self-image (Gneezy et al. 2012). Apart from the purely normative or psychological causes, consumers might also pay under PWYW with the strategic intention to keep the PWYW seller in the market (Schmidt et al. 2015). Mak et al. (2015) provided analytical and experimental evidence on how this motivation could transform PWYW into a major variant of VCM with threshold public-good provision (Croson and Marks 2000) and lead to long-term profitability for the seller. Mak et al. (2015) further showed how consumer communication could facilitate this possibility in practice.

PWYW, gift giving, and donations are closely related, because all three can be grouped as voluntary payment mechanisms (see the discussion in Natter and Kaufmann, 2015). In fact, PWYW can be seen as donations with a clearly defined immediate gain for the donor. The relationship with donation behavior implies PWYW is subject to a host of social psychological factors that have been studied in the larger literature concerning donations, but await research on their specific roles in PWYW. On the other hand, PWYW also connects with other participative pricing mechanisms such as NYOP. Recently, the experimental research by Krämer et al. (2017) has noted how both NYOP and PWYW can achieve different degrees of price discrimination as well as market penetration in a competitive market, complementing similar work on PWYW by Schmidt et al. (2015).

More research is needed to determine which participative pricing mechanism (e.g., NYOP, PWYW, or auctions with buyer competition) is best suited for specific situations (e.g., based on product characteristics or the competitive situation of the seller(s)), as well as how effective each mechanism is in price discrimination, market penetration, and competition. Further, the role of 
uncertainty in PWYW pricing requires a more nuanced study. In addition to the seller's uncertainty in the payment amount received from the buyer, buyers can face "endogenous" uncertainty related to the price they pay and the seller's reaction to it: in addition to sellers' subsequent entry decisions, buyers' payment may influence the quality of the product they receive (e.g., in case of payment before the service). A related research question concerns the timing of the payment (before or after the service) in the price-setting stage.

\section{Participative Pricing with Buyer Competition: Auctions}

This section focuses on auctions, which are participative pricing mechanisms with buyer competition. Buyer competition in participative pricing results in increased competitive intensity, which in turn results in specific types of emotions, such as competitive arousal and desire to win. As a result, studying how the competitive intensity and related emotions influence bidder behavior and willingness to pay (WTP) as well as factors that moderate or mediate this relationship is important. Another related issue is the dependencies between competing auctions that may run simultaneously or sequentially. An important consideration for auction sellers is to determine the best way to sell items in multiple auctions (i.e., simultaneous, sequential, or partially overlapping auctions), and what factors influence this decision.

\subsection{Auctions with and without active seller participation}

Table 1 distinguishes between auctions according to whether the seller can actively participate after the buyer submitted a bid. Auctions without the seller's active participation are auctions in which the seller determines the auction mechanism (e.g., a public reserve price) but has no influence over the outcome after the auction has started. This format is in contrast to auctions in which the seller has direct influence over the outcome, such as auctions with a secret reserve, 
where the seller has the right to refuse a bid, and in most $\mathrm{B} 2 \mathrm{~B}$ auctions. ${ }^{5} \mathrm{~B} 2 \mathrm{~B}$ auctions will be discussed in section 6.1.

Little research has investigated the difference between auctions with and without active seller participation. Some related research has looked at the effect of secret reserve prices in auctions. ${ }^{6}$ Research has shown a secret reserve may result in reduced bidder entry, because bidders may form an expectation that the level of the reserve is above their WTP, which in turn leads to lower selling prices (Vincent 1995, Katkar and Reiley 2006). However, secret reserves may have a positive effect on ending prices, because they may act as additional bidders (Elyakime et al. 1994). Bajari and Hortaçsu (2003) reported higher selling prices in auctions with secret reserves compared to open reserves. Another tool that provides sellers with input, introduced in 2005 by eBay auctions, is the best-offer mechanism. In auctions with a best-offer option, a bidder can make an offer on an item, after which the seller has the option to accept or reject the offer, or to make a counteroffer. Little or no research has been conducted examining this mechanism, though a significant amount of research has focused on a similar mechanism, NYOP (discussed in section 3.1).

\subsection{Bidder behavior and auction design}

We restrict our attention to a simple auction, which is a pricing mechanism whereby bidders submit bids, and one of the bidders wins and pays a price based on his bid. More complex auctions allocate

\footnotetext{
${ }^{5}$ As noted in section 2, many B2B auctions are procurement reverse auctions in which the product to be sold is, for example, a bridge-building contract offered by a state government (the seller), with contractors playing the roles of buyers.

${ }^{6}$ In most local (and B2B) auctions, the seller (buyer) has an option to reject a high bid when a secret reserve price is used. However, in eBay auctions, the seller needs to pre-specify the level of the reserve, and the outcome is binding as soon as the secret reserve is met.
} 
more than one unit of a good, allow multi-dimensional bids, and so on. Although various complex auction formats and auction features exist beyond the scope of the present work, all auctions are clearly a participative pricing mechanisms in the strict sense of meeting the two criteria we specified. Instead of trying to cover many different formats and features, we focus on one behaviorally important distinction within simple auctions: the difference between sealed-bid and open auctions. In an open auction, bidders submit bids throughout the auction until termination. With sealed bidding, participating bidders independently submit bids; the highest bidder wins and pays his bid. Although both forms are participative according to the two criteria we highlighted, the open auction has additional strength as an empowering mechanism.

Empowerment. From a behavioral perspective, a participative pricing mechanism bestows on the consumer a sense of control and empowerment. Wathieu et al. (2002) provide a comprehensive summary of the characteristics constituting consumer empowerment. Their work did not deal with pricing in that mix, but was rather focused on the consumer ability to control the choice set and attributes. Nevertheless, many of these empowerment characteristics they listed hold for pricing as well. Specifically, they identified three components of consumer empowerment: (1) control, (2) progress cues, and (3) information about other consumers. In the context of auctions, control, according to Wathieu et al. (2002), implies a consumer's ability to specify and adjust, which naturally maps the process of bidding to participative pricing. The desire for control leads to the second characteristic of consumer empowerment: progress cues. In open auctions, consumers can track the progress of bidding and can respond in real time to changes in information, whether this information involves other bids or other auctions (Pilehvar, Elmaghraby, and Gopal 2016). In general, an auction will be perceived as bestowing greater empowerment when the pricing mechanism is perceived as being more extended, complex, adaptive, and open ended (the 
criteria Wathieu et al. [2002] identified as important for progress cues). Again, open auctions are advantaged relative to sealed-bid auctions. Lastly, to create perceived control, one must provide information about other consumers' bids to the extent possible. Open auctions provide feedback about others' bids before the auction is concluded, making it of greater participative value, according to the empowerment criteria identified by Wathieu et al. (2002). In the context of eBay auctions, Zeithammer and Adams (2010) provide indirect evidence for the importance of empowerment to consumers, by showing even last-minute bids by the two highest bidders in each auction cannot be interpreted as if they came from a sealed-bid auction, despite eBay encouraging sealed bidding via the "proxy bid" system (i.e., eBay recommends bidders place a proxy bid equal to their WTP, and have the proxy bidding system bid on their behalf). Instead, most eBay bidders seem to value the above three elements of empowerment, and bid in reactive fashion all the way to the end of the auction.

Emotions. The empowerment aspect of participative pricing in auctions cannot be considered in isolation from emotions and the value of excitement that auctions bestow on consumers due to participative pricing. According to Bapna, Goes, and Gupta (2001), consumers' desire to experience a "bazaar-like competitive atmosphere" drives their purchase decisions (p. 44). Stafford and Stern (2002) argued the emotions bidders experience in online auctions are themselves a source of added utility compared to non-participative formats. Lee, Kim, and Fairhurst (2009, p. 93) argued the "thrill of bidding, excitement of winning, [and the] stimulation of beating competitors" are key in consumers' preference for auctions. Herschlag and Zwick (2000) claimed that "winning is the aphrodisiac that gets the shopping juices flowing" (p. 170). Astor et al. (2013) tested this emotion argument with skin conductance response (SCR) and heart rate (HR) as proxies for both the intensity and the valence of emotions. They demonstrate - in sealed-bid auctions- 
that the HR responses when losing an auction are stronger than when winning an auction, whereas winning an auction induces a stronger SCR compared with losing an auction. Such physiological evidence for the psychological effects of participative pricing is increasingly important in academic research on participative pricing, which is not surprising given the convergence to an academic consensus that the value of participative pricing is in large part emotional. Haruvy and Popkowski Leszczyc (2010b) argued the critical aspect to consider in determining auction outcomes is "the dynamic interaction among bidders in an ascending bid auction" (p. 100). Accordingly, Haruvy and Popkowski Leszczyc (2016) modeled a complex four-component auction process that involves (1) the choice between auctions, (2) the timing of the bid, (3) the bid amount, and (4) the payment for the auction. Within that process, they found competitive responses to be an important determinant of bidding behavior. More generally, the literature has identified accelerated competitive reactions as "competitive arousal," or alternatively as "auction fever." With competitive arousal, the bidders' "adrenaline starts to rush, their emotions block their ability to think clearly, and they end up bidding much more than they ever envisioned" (Murnighan 2002, p. 63). Ku, Malhotra, and Murnighan (2005) provided extensive empirical evidence for competitive arousal from live and internet bidding, survey data, and laboratory experiments. They concluded competitive arousal from open auctions results in higher bids and revenues.

Competitive intensity. Häubl and Popkowski Leszczyc (2016) studied the effect of speed of competitor reaction (how fast a bidder is outbid by another bidder) on WTP in an auction. Results from five experiments provide strong support that faster speed of competitive reaction results in a higher WTP. Furthermore, they showed this effect is mediated by the perceived competitive intensity of the auction, which in turn increases a bidder's desire to win the auction, resulting in more persistent bidding and a higher WTP. In addition, they showed the effect of the speed of 
competitor reaction is distinct from competitive arousal, any impact due to time pressure or auction duration, inferences about the product's value, or the nature and number of competing bidders.

Behavior in a sequence of auctions. Emotions are important both within and across auctions, particularly when auctions are in sequence. Ding et al. (2005) identified the resulting sequential dependencies due to bidder emotions. They examined the role of bidder emotions in a NYOP mechanism they specifically identify as a degenerate form of a reverse auction. In that context, they provided a formal representation of the emotions evoked by the auction process, specifically, the excitement of winning if a bid is accepted, and the frustration of losing if it is not. They then generated and empirically tested a number of insights related to (1) the impact of expected excitement at winning, and frustration at losing, on bids across consumers and bidding scenarios, and (2) the dynamic nature of the bidding behavior, that is, how winning and losing in previous auctions influence subsequent bids. They report bidder frustration and a decreased propensity to bid after losing an auction. Emotion-driven sequential dependency is also evident in Pilehvar et al. (2016). Using data from auctions hosted on an online B2B platform, Pilehvar et al. (2016) show bidders are influenced by prices from their own previous bidding behavior as well as concurrent prices in other auctions relative to the focal auction.

Dependencies between simultaneous and sequential auctions. Several papers have studied simultaneous and sequential ascending-bid auctions. Simultaneous auctions are fully overlapping and allow for bidders to cross-bid or switch among auctions. Cross-bidding among simultaneous auctions has been empirically observed (Anwar, McMillan, and Zheng 2006; Haruvy and Popkowski Leszczyc 2010; Haruvy, Popkowski Leszczyc, and Ma 2014) and results in increased bidders and bids in both auctions, and thus tends to increase sellers' revenues (Beil and Wein 2009). In addition, empirical results find cross-bidders pay less than non-cross-bidders in eBay auctions 
(Answer et al. 2006). Haruvy, Popkowski Leszczyc, and Ma (2014) studied simultaneous and partial overlapping auctions. They found the degree of overlap between auctions, the number of simultaneous auctions, and information transparency influence bidding behavior and auction outcome. Further analyses of clickstream data (search) indicated bidder search mediates the latter effect on price dispersion.

Bidding in sequential auctions differs because bidders can only bid in one auction at a time, but when placing bids, they tend to take into account information about future auctions (i.e., they are forward-looking), resulting in less aggressive bidding and lower prices in earlier auctions (Zeithammer 2006). Zeithammer (2007a, b) expanded this work by incorporating sellers' learning, where sellers either decide to host future auctions, based on prices from previous auctions (Zeithammer 2007a), or some sellers learn whereas others do not, and commit to hold additional auctions at the beginning of the game (Zeithammer 2007b). However, bidder learning about product values from preceding auctions reduces uncertainty, which tends to result in aggressive bidding (and higher prices) in later auctions (Kagel and Levin 1986; Kim and Che 2004).

Sequential dependencies within open auctions. Haruvy and Popkowsky Leszczyc (2010a) and Lim, Haruvy, and Popkowsky Leszczyc (2016) characterized sequential dependencies within open auctions. Lim et al. (2016) showed current information displayed on concurrent auctions affects the bids submitted through a complex sequential process beginning with (1) which auctions to visit, (2) which auction to bid in, and (3) what amount to bid. Lim et al. (2016) showed these sequential dependencies are driven primarily by the propensity to search, which is a function of information and history.

To summarize, auctions as a participative pricing mechanism are effective at increasing revenues, in part due to behavioral considerations including empowerment, emotions, sequential 
dependencies, and competitive arousal. These behavioral effects are in turn dependent on careful auction design, starting with the decision regarding whether to conduct a sealed-bid or open format.

Future research is needed to determine the conditions under which competitive intensity and arousal influence bidding behavior and auction outcome, and what factors mediate or moderate this relationship. In addition, more research is needed to study optimum strategies for selling competing products. In particular, under what conditions is it best to use either sequential, simultaneous, or partial overlapping auctions? Also, what is the best way to sell complementary products either as separate components or as bundles (e.g., Popkowski Leszczyc, and Häubl 2010)? Finally, more general research is needed to compare the differences between participative pricing with and without buyer competition. For a seller, what participative pricing strategy generates the highest revenue?

\section{Outcome and Process Utility in Participative Pricing}

A reasonable assumption about consumers is that they welcome the opportunity to influence the purchase price. Because people generally prefer to pay less for the products and services that interest them, any mechanism that transfers (some) control over the final price must be appealing.

In reality, however, consumers often behave in a manner that contradicts this intuition. For example, several studies reveal people are remarkably generous under a PWYW regime: they pay significant sums for something they can actually have for free. A common explanation for this observation is that participative pricing mechanisms prime some social preference-including altruism, inequity aversion, and reciprocity — that, in turn, motivates payments (Gneezy et al. 2010; Haws and Bearden 2006; Kim, Natter, and Spann 2009; Regner and Barria 2009; Schmidt, Spann, and Zeithammer 2015). Alternatively, Mak et al. (2015) posit that PWYW, the most extreme participative pricing mechanism, in effect transforms a private good into a public one, and 
consumers understand their payments in the present guarantee the provision of the good in the future. Finally, in the context of auctions, Ding et al. (2005) show theoretically and empirically that emotions such as excitement and frustration aroused by the pricing mechanism itself (the "joy" and "frustration" of the game) affect the magnitude of bids.

Another observation that contradicts the above intuition is that, far from being delighted, many consumers who are offered control over the final price decide to opt out of the purchase altogether. According to Gneezy et al. (2012), identity and self-image concerns motivate this response: people who want to pay less than a figure they consider appropriate or reasonable experience embarrassment, which, if sufficiently strong, pushes them to abandon the purchase (for similar arguments, see Ariely, Bracha, and Meier [2009] and Hazard [2016]). Alternatively, Chernev (2003) and Spann et al. (2012) argue consumers naturally prefer to select rather than generate prices, particularly when no salient reference point exists: the absence of a clear benchmark results in decision fatigue, which can lower interest in the purchase. Similarly, Einav et al. (forthcoming) demonstrate with data from eBay that people are essentially willing to pay a premium for products to avoid the (perceived) hassle costs of taking part in auctions. ${ }^{7}$

Reconciling the way consumers ought to react to participative pricing mechanisms with the way they actually do is possible if we consider the possibility that individuals derive satisfaction or dissatisfaction from not only outcomes (the difference between what they get and what they give up in a transaction), but also the underlying processes that generate them. A formal descriptive account of utility from the process, hereby defined as the subjective experience evoked by

\footnotetext{
${ }^{7}$ Casual empiricism aligns nicely with this finding. For instance, recently several car manufacturers instituted "no haggling" policies at dealerships to attract the business of customers, primarily women, who are put off by the thought of bargaining with a car salesperson.
} 
participation in the process of setting a price, may have the following characteristics. ${ }^{8}$

Consider a market in which a firm sells a product to consumers. The firm incurs a marginal production cost of $c$ per unit, with $0<c<1$. Each consumer purchases at most one unit of the product, and $r_{i}$, is consumer $i$ 's WTP for the product. To capture heterogeneity, we let $r$ be a random variable that is drawn from a probability density function $\phi(r)$, with the corresponding cumulative distribution function $\Phi(r)$ defined over $[0,1]$. We consider cases in which the firm chooses to let consumers participate in the pricing decision. Consumer $i$ 's utility from purchasing a product is given by

$$
u_{i}=r_{i}-p_{i}-\beta \max \left\{\left(p_{i}-r_{i 0}\right), 0\right\}-\gamma \max \left\{\left(r_{i 0}-p_{i}\right), 0\right\}+\delta \tau\{\text { pricing strategy }\}
$$

where $p_{i}$ is the price paid by consumer $i$, and $r_{i 0}$ is the "fair" price perceived by the consumer.

The parameters $\beta$ and $\gamma$ are two positive constants such that $\beta \max \left\{\left(p_{i}-r_{i 0}\right), 0\right\}$ captures the consumer's disutility toward disadvantageous inequality and $\max \left\{\left(r_{i 0}-p_{i}\right), 0\right\}$ captures the consumer's disutility toward advantageous inequality (Fehr and Schmidt 1999). The parameter $\delta$ is a constant that captures the consumer's utility (or dis-utility) from participating in setting prices, and $\tau$ \{pricing strategy\} is a function that captures the amount of consumer participation in the pricing strategy, such that $\delta \tau\{$ pricing strategy\} captures the overall (dis)utility from the consumer's participation. Chao, Fernandez, and Nahata (2015) analyze an analogous theoretical model, showing PWYW pricing can be more profitable than posted pricing. They identify another benefit: increased efficiency of the market.

In our mind, the first opportunity for research on utility from process is to create a

\footnotetext{
${ }^{8}$ Note our concept of utility from process is not unique in the domain of pricing. For example, considerable research has investigated the perceptions of fairness in response to the pricing actions of sellers. Importantly, fairness typically has two dimensions: one related to the outcome (the price level) and another related to the process (how the price came to be) (Campbell 1999).
} 
comprehensive catalog of motivating factors. The impact of participating in the pricing decision on purchase behavior has different origins. We already discussed social preferences, uncertainty, decision fatigue, decision conflict, image concerns, and emotions, but other sources are likely, both situational and dispositional. In particular, the need exists to make sense of this landscape, and as such, a useful contribution may be a conceptual framework that unifies and puts order to the current knowledge.

Second, and perhaps more important, different theories have different consequences on the likelihood of making a purchase and/or actual payments. Another issue is identifying and examining moderating variables that determine the direction of the net effect. One example is the work of Chandran and Morwitz (2005), which shows PWYW increases purchase incidence and generates revenue on par with the standard posted-price regime only for people who enjoy negotiations and usually take an active part in the shopping process (those considered to have a higher degree of control over their shopping decisions).

The third avenue we see for future research is to distinguish between direct and indirect links from process utility to outcomes. Direct links are more conventional: consumers derive pleasure or pain from the pricing mechanism itself, which affects their purchase behavior. But this pleasure or pain may also change (in ways that perhaps escape awareness and volition) how consumers perceive payoffs, in which case the impact is indirect. For example, how responses are collected might affect bidding behavior. Response formats vary not only across the physical and virtual domain, but also within each type. A case in point is Priceline's approach to NYOP on its website versus its mobile application: the company uses an open-ended textbox to elicit bids on the website, but a sliding scale to do the same on the mobile application. Meanwhile, Thomas and Kyung (2017) demonstrated through a series of experiments that sliding scales intensify aggressiveness and 
influence bid values.

Finally, an interesting question is whether consumers habituate to pricing mechanisms. That is, although the process may influence consumers at first, is this relation consistent across time and exposures? One argument against a sustained effect is that with repetition come norms, and therefore consumers naturally become sensitized.

\section{Applications of Participative Pricing in Selected Domains}

In this section, we discuss applications of participative pricing mechanism in three domains: B2B, advertising, and charity auctions. We selected B2B mechanisms because they constitute the largest proportion of electronic commerce in dollar terms (Lucking-Reiley and Spulber 2001). ${ }^{9} \mathrm{We}$ selected advertising, because in terms of number of auctions being run daily, advertising auctions have no match — more than a hundred million advertising auctions take place per day (Försch et al. 2017). We selected fundraising because it is a fast-growing sector of the economy (Giving USA, 2017), wherein innovative participative pricing methods are both sorely needed and readily adopted (Huck and Rasul 2011; Shang and Croson 2009; Eckel, Herberich, and Meer 2017), but also because charity and fundraising are the most naturally occurring applications of PWYW pricing, which is one of the main mechanisms discussed in this article.

\subsection{Business-to-business transactions}

Most of the work on $\mathrm{B} 2 \mathrm{~B}$ auctions are participative reverse auctions in which a buyer initiates a bidding event and potential suppliers bid the prices down; these events are generally buyer

\footnotetext{
${ }^{9}$ US B2B e-commerce sales are expected to top $\$ 1$ trillion by 2019; see Forrester Research B2B e-Commerce Forecast, 2015 to 2020 at https://www.pepperi.com/wholesale-ecommerce/.
} 
determined (Jap 2003) ${ }^{10}$ meaning the auction may not determine the ultimate winner, as additional non-price criteria are considered in the winner selection.

Differentiated bidders. Such mechanisms are necessitated because of product, service and bidder heterogeneity. One response has been the use of multidimensional pricing mechanisms in which the buyer specifies its ex-ante weights for non-price aspects (Anton and Yao 1987; Boger and Liao 1988, Chen-Ritzo et al. 2005, Mayer 1987, Riordan and Sappington 1987). In practice, these mechanisms are cumbersome, because the weights can be difficult to determine in advance. An alternative is to couple a price-based mechanism with forms of non-competitive contracts (Engelbrecht-Wiggans, Haruvy, and Katok 2007) or to use a two-stage process (Tunca and Wu 2009).

More recent research has focused on the role of information. Bidders pay higher prices when winner identities are concealed (Lu et al. 2016); anonymizing winning bids might discourage tacit collusion and declining prices. Pilehvar et al. (2016) find first bidders are influenced by their past bidding behavior (an internal reference price) and also monitor concurrent prices in other open and just-finished auctions (external reference prices), and these behaviors are moderated by bidder heterogeneity (i.e., a bidder's experience and cross-bidding across comparable concurrent auctions).

Interorganizational relationships. Relationships between the participants also critically influence mechanism performance and outcomes. The most robust result is that auctions reduce trust, increase dysfunctional conflict, and ultimately undermine suppliers' non-price performance in the exchange (Carter and Kaufmann 2007). Research also shows auctions increase suspicions

\footnotetext{
${ }^{10}$ As noted in section 2, a B2B procurement reverse auction can also be viewed as an auction wherein the product to be sold is a contract offered by the procuring company or government (the seller), with suppliers playing the roles of buyers.
} 
of buyer opportunism, even when the buyer is not acting opportunistically (Jap 2003, 2007). Auctions not only sour bidder satisfaction with the buyer, but also alter the bidder's propensity or willingness to strengthen or improve its relational position with the buyer (Jap and Haruvy 2008).

Relationships have been shown to alter bidding strategies and aggression; high-quality bidders are more aggressive against potentially higher-quality competition and less aggressive against lower-quality competitors (Haruvy and Jap 2013). By contrast, low-quality bidders bid aggressively regardless of their implied quality vis-a-vis the competition. Extant organizational relationships incorporate differentiation information and lead bidders to adjust their bidding strategy accordingly.

Future research. PWYW mechanisms might be effective for acquiring new service customers. Design firm StackSocial offers its customers a designer bundle of products, each with a suggested price. ${ }^{11}$ People who pay above the average price receive the entire bundle, and all others receive a reduced version. From the seller's perspective, what part of the offering is acceptably "free" or not paid for? Do customers understand this offer? How does such a mechanism compare to a target conversion rate or move customers along a conversion life cycle? Susan Graham (Susan G IT Consulting) leaves the amount of the first month's fee up to the customer, and this approach has led to significant annual growth and heightened trust. Previously, clients would be guarded, but with a PWYW model, they valued her more because they could determine how much her services were worth to them.

Another direction is the roles of guarantees, premiums, and penalties. Suppliers might offer a guarantee, or commit to product ownership if it does not sell, and charge sellers a commission for prices that exceed the guarantee. This approach profits sellers at the expense of the market

\footnotetext{
${ }^{11}$ From https://stacksocial.com/sales/pay-what-you-want-b2b-designer-bundle, accessed on 12/1/2016.
} 
maker when sellers are powerful (cf., Greenleaf et al 2002). Suppliers might also use buy-in penalties with sellers to motivate a lower reserve to increase expected revenues. Greenleaf and Sinha (1996) have found these typically Pareto-dominated pricing mechanisms rely on seller commissions.

\subsection{Advertising}

Historically, most advertisements were sold by sales representative who either used a posted price or negotiated a long-term contract with a uniform price for all ads. This pricing mechanism was essentially turned upside down when search engines such as Yahoo and Google started to use auctions and not posted prices to sell advertising slots in their search-engine results (Varian and Harris 2014). In response, search-engine marketing became the most prominent online marketing instrument in most countries, and nowadays, all prominent search engines, namely, Google, Bing, and Yahoo in Western countries, and Baidu and Yandex in China and Russia, sell their ad slots in their search-engine results via real-time auctions.

Not until years later were real-time auctions also used to sell slots for online display advertisements, which created the "real-time bidding" (RTB) industry. Today, however, nearly every time a user visits a website (Lee, Jalali, and Dasdan 2013; Varian and Harris 2014), an auction takes place to sell the respective advertisement for this user. Often an ad exchange is used that runs these auctions in less than 200 milliseconds. Försch, Heise, and Skiera (2017) report on an advertising exchange that performs on average 97.5 million auctions per day, which equals 1,128 auctions per second. Obviously, computer algorithms bid on behalf of (human) advertisers according to pre-specified bidding strategies. These auctions offer advertisers an opportunity to buy each impression at a price that reflects the value of a single impression, and publishers can sell each impression to the highest-bidding advertiser. 
Most of these auctions are second-price sealed-bid auctions, which show large similarities with Vickrey auctions. In terms of the number of transactions, the "Vickrey" auction is thus by far the most popular auction format in history (Zeithammer 2016). However, the RTB industry was innovative in making small changes to Vickrey auctions, which creates fascinating opportunities for future research. Among these changes are soft floors and hard floors. The hard floor acts as a minimum price below which an impression is not sold. It is similar to what the auction literature usually calls a reserve price. The soft floor turns the second-price auction into a first-price auction if the advertiser bids below the soft floor (Försch, Heise, and Skiera 2017; Zeithammer 2016). The theoretical analysis of Zeithammer (2016) suggests soft floors should not have any impact on the seller's profit, but the empirical study of Försch, Heise, and Skiera (2017) outlines it does. The reason is that Zeithammer (2016) captures the equilibrium that will be reached in the long term, and Försch, Heise, and Skiera (2017) look at short-term reactions. An interesting but open question is how long it will take to reach the equilibrium.

Another interesting future research area deals with the design of the auctions to sell advertising slots. Edelman, Ostrovsky, and Schwarz (2007) and Varian and Harris (2014) outline the subtle differences between Vickrey-Clarke-Goves (VCG) auctions (of which the Vickrey auction is a special case) and generalized second-price (GSP) auctions. Bidding the true value is a dominant strategy in VCG auctions but not in GSP auctions. Still, which one is more profitable is not clear, and sellers also sometimes provide more weight to the bid of some advertisers or reveal more information to some advertisers than others. A better understanding of the impact of these alternative auction designs on the profit of sellers and buyers is certainly required.

\subsection{Charity auctions and fundraising}

Price premiums in charity auctions. An important question for academics and practitioners is the 
price premium consumers are willing to pay for charity. Participative pricing mechanisms are in particular suitable for charity settings in which consumers may be willing to pay a premium. Charity settings have widely used auctions in particular. Several papers have compared charity versus non-charity auctions and have measured the premium consumers are willing to pay (Elfenbein, Fisman, and McManus 2012; Elfenbein and McManus 2010; Haruvy and Popkowski Leszczyc 2009; Popkowski Leszczyc, and Rothkopf (2010). The donation percentage (Haruvy and Popkowski Leszczyc 2009, Popkowski Leszczyc and Rothkopf 2010), seller reputation (Elfenbein et al. 2012), and the type of product (Popkowski Leszczyc et al. 2015) moderate this charitable premium.

Bidder charitable preferences or motivations. Research has suggested bidders are willing to pay a premium in charity auctions because they obtain additional utility from money going to charity (Goeree et al. 2005). Studies of charitable motives have found charitable bidders receive utility from charity, even when they lose, providing them with an incentive to drive up prices (He and Popkowski Leszczyc 2013; Popkowski Leszczyc et al. 2015; Popkowski Leszcyc and Rothkopf 2010). Finally, Haruvy, and Popkowski Leszczyc (2009) found segments with different charitable preferences: a non-charitable or selfish segment, a segment that gives for selfish reasons (a warm-glow segment), and a segment that gives for selfless reasons. These segments differed significantly in the charitable premium they were willing to pay in charity auctions. The selfless segment was willing to pay a significantly higher premium for greater donations to charity.

Fundraising format. The all-pay auction, in which every bidder pays his highest bid, is an increasingly popular auction format with the potential to generate higher revenues (Engers and McManus 2007). An all-pay auction is a type of auction in which all bidders pay some amount regardless of whether they win (Kim et al. 2014). Applications of all-pay auctions include papers 
on penny auctions (Platt, Price, and Tappen 2013; Augenblick 2015) and charity auctions (Carpenter, Homes, and Matthews 2008). ${ }^{12}$

Haruvy and Popkowski Leszczyc (2016) conducted a large-scale field experiment comparing revenue and bidding behavior in winner-pay and voluntary-pay auctions in both charity and non-charity settings. The volunteer-pay auction is a specific variety of the all-pay auction in which losing bidders are asked to pay an amount equal to their highest bid. The authors found significantly higher revenues in the volunteer-pay auctions than in the winner-pay format in a charity setting. However, those results are reversed in a non-charity setting. This finding suggests such auction formats are well suited for charity settings, wherein losing consumers are less concerned with paying, because the money goes to a good cause.

Future research in charity auctions and fundraising. Empirically testing alternative auction formats in a charity setting is needed, including different all-pay formats in charity settings, in which bidders have to pay a fee for bidding (Kim et al. 2014; Spann, Zeithammer, and Häubl 2010). More research is also needed to study how different motivations influence consumers' WTP in charity auctions and in cause-related marketing settings (Koschate-Fischer, Stefan, and Hoyer 2012, Andrews et al. 2014), and how consumers respond to small-donation promises. Future research should also focus on other participative pricing mechanisms in a charity setting. Gneezy et al. (2010, 2012) studied PWYW pricing in a charity setting. Gneezy et al. (2010) reported significantly higher profitability with PWYW prices than with fixed prices, when $50 \%$ of proceeds were donated to charity.

\footnotetext{
${ }^{12}$ In penny auctions, bidders need to pay a fee for each bid placed in an auction (websites currently in operation are Beezid.com, QuiBids.com, BidSauce.com, DealDash.com, and HappyBidDay.com).
} 


\section{Conclusion}

Participative pricing mechanisms offer several highly promising avenues for future research, which we discussed in sections 3-6 according to our taxonomy outlined in Table 1. Table 2 provides an overview of specific research questions related to each participative pricing mechanism.

Table 2: Research questions for participative pricing mechanisms

\begin{tabular}{|c|c|c|}
\hline $\begin{array}{c}\text { Class of } \\
\text { Mechanism } \\
\text { / Topic }\end{array}$ & $\begin{array}{l}\text { Mechanism } \\
\text { / domain }\end{array}$ & Research Questions \\
\hline \multirow{2}{*}{$\begin{array}{l}\text { No Buyer } \\
\text { Competition } \\
\text { Interactive }\end{array}$} & NYOP & $\begin{array}{l}\text { - Profitability of NYOP compared to posted pricing } \\
\text { - Impact of transaction environment on profitability } \\
\text { - Buyer behavior and deviations from rationality } \\
\text { - Optimal design of NYOP } \\
\text { - Outcome and process utility of NYOP }\end{array}$ \\
\hline & Bargaining & $\begin{array}{l}\text { - Combination of bargaining with other participative } \\
\text { pricing mechanisms } \\
\text { - Choice between bargaining formats (e.g. deadlines, } \\
\text { counter offers) }\end{array}$ \\
\hline $\begin{array}{c}\text { No Buyer } \\
\text { Competition } \\
\text { Not interactive }\end{array}$ & PWYW & $\begin{array}{l}\text { - Generalization of applicability of PWYW for } \\
\text { specific situations } \\
\text { - Analysis of the role of uncertainty in PWYW (e.g., } \\
\text { buyer's uncertainty on what is a fair price) } \\
\text { - Timing of payments in PWYW (e.g., before or after } \\
\text { service) }\end{array}$ \\
\hline $\begin{array}{c}\text { Buyer } \\
\text { Competition } \\
\text { Interactive }\end{array}$ & $\begin{array}{l}\text { Auctions with active } \\
\text { seller participation }\end{array}$ & $\begin{array}{l}\text { - Impact of auction design on perceived buyer } \\
\text { empowerment and emotions } \\
\text { - How competitive intensity and arousal influence } \\
\text { bidding behavior and auction outcome } \\
\text { - Analysis of eBay best offer mechanism } \\
\text { - Competing products: under which conditions use }\end{array}$ \\
\hline $\begin{array}{c}\text { Buyer } \\
\text { Competition } \\
\text { Not interactive }\end{array}$ & $\begin{array}{l}\text { Auctions without } \\
\text { active seller } \\
\text { participation }\end{array}$ & $\begin{array}{l}\text { sequential, simultaneous, or partial overlapping } \\
\text { auctions } \\
\text { - Complementary products: sell as separate } \\
\text { components or as bundles }\end{array}$ \\
\hline
\end{tabular}




\begin{tabular}{|c|c|c|}
\hline & & $\begin{array}{l}\text { - Compare the differences between participative } \\
\text { pricing with and without buyer competition }\end{array}$ \\
\hline $\begin{array}{l}\text { Outcome and } \\
\text { process utility }\end{array}$ & all & $\begin{array}{l}\text { - Classify specific effects of process utility } \\
\text { - Consequences of different effects of process utility } \\
\text { - Differences between direct and indirect links from } \\
\text { process utility to outcomes } \\
\text { - Consumer learning and habituating to participative } \\
\text { pricing mechanisms }\end{array}$ \\
\hline \multirow{3}{*}{$\begin{array}{l}\text { Areas of } \\
\text { application }\end{array}$} & B2B & $\begin{array}{l}\text { - Explore PWYW for service components in B2B } \\
\text { transactions } \\
\text { - Explore the role of price guarantees, premiums, and } \\
\text { penalties in B2B transactions }\end{array}$ \\
\hline & Advertising & $\begin{array}{l}\text { - Analyze the effect of hard and soft floors in } \\
\text { second-price sealed-bid auctions } \\
\text { - Analyze differences between auction designs to sell } \\
\text { advertising slots (e.g., VCG and GSP auctions) }\end{array}$ \\
\hline & Charity & $\begin{array}{l}\text { - Test different participative pricing mechanisms in a } \\
\text { charity setting (auction and PWYW formats). } \\
\text { - How do consumers respond to small donation } \\
\text { promises in cause related marketing settings }\end{array}$ \\
\hline
\end{tabular}

Summarizing the mechanism-specific questions (see Table 2), we can identify three areas for future research on participative pricing mechanisms:

The first set of research questions focuses on the prevalence, profitability, and optimal design of participative pricing mechanisms. More research is needed that compares different participative pricing mechanisms to determine which mechanisms are most suitable (profitable) and under what conditions. We discussed why NYOP is not more frequently used and how this underutilization may be related to current NYOP sellers not (yet) adopting optimal design recommendations. Related, a further investigation of the downstream consequences of participative pricing mechanisms may identify not only additional benefits (e.g., satisfaction, repeat purchases, word of mouth), but also obstacles (e.g., revenue dilution) that may explain the mechanisms' limited popularity. Additionally, the nature of uncertainty (for the seller: cost of 
goods sold; for the buyer: acceptance of bid and experienced utility) and the timing of the payment (i.e., before or after the service) are likely to affect seller profitability and buyer behavior.

A second set of research questions relates to bidder/buyer behavior in participative pricing mechanisms. The task to come up with a dollar number for a bid/offer can be challenging for consumers, and the behavioral mechanisms behind this process need better understanding. Related, we see consumers opt out of participating in price settings (e.g., in PWYW). An explanation worth investigating in addition to the outcome utility is the idea of "process utility" (the process to get to the outcome). Modeling process utility (which may include cognitive costs, image concerns, etc.) seems like a fruitful avenue to better understand when customers participate in pricing. As noted in section 5, cataloging the various drivers of process utility-cognitive fatigue, enjoyment, bidding frenzy, metacognitive uncertainty—would be managerially relevant as well as theoretically insightful. Additionally, delineating the direct and indirect effects of process utility on transactions is a promising area for further research. Several factors such as response formats can subtly influence process utility, without the consumers' awareness or volition, and thus indirectly change outcome utility.

A third set of research questions relates to new participative pricing formats and specifics of the application of participative pricing mechanisms in the business-to-business domain. For example, we observe an increased application of the all-pay auction format, such as keywordsearch auctions, crowdsourcing, and procurement (i.e., all instances in which bidders need to make some initial investment but only one winner might be possible). However, empirical applications are almost non-existent. Therefore, determining the revenue implications and bidding strategies of bidders in this format is important. How do all-pay auctions perform relative to winner-pay auctions? Also, how does this format perform in charity and non-charity settings? Within the 
business-to-business domain, particularly in the area of industrial purchasing, infinite opportunities remain for better understanding the phenomenon of participative pricing. Research has not considered the effectiveness of mechanisms such as PWYW and NYOP in the context of ongoing industrial procurement relationships. Relational exchanges between organizations are those marked by a high degree of trust and commitment, both perceived and real. In such a context, one could expect to see very different PWYW and NYOP responses, because the social and exchange norms between the players might powerfully alter or even reverse their choice responses from that of a single-encounter transaction or even a transactional relationship context.

Ultimately, an increased understanding of these key theoretical insights benefits all researchers studying questions of customer-driven pricing mechanisms. By understanding how the behavioral factors drive buyer behavior and seller profit, we see a rich array of avenues for future research as well as managerial practice. 


\section{References}

Amaldoss W, Jain S (2008) Joint bidding in the name-your-own-price channel: A strategic analysis. Management Science 54(10):1685-1699.

Andrews M, Luo X, Fang Z, Aspara J (2014) Cause marketing effectiveness and the moderating role of price discounts. Journal of Marketing 78(6) 120-142.

Anton JJ, Yao DA (1987) Second Sourcing and the Experience Curve: Price Competition In Defense Procurement. RAND Journal of Economics 18 (1) 57-76.

Anwar S., McMillan R., Zheng M (2006) Bidding Behavior in Competing Auctions: Evidence from eBay. European Economic Review (50:2) 307-322.

Ariely D, Bracha A, Meier S (2009) Doing Good or Doing Well? Image Motivation and Monetary Incentives in Behaving Prosocially. American Economic Review 99 (1) 544-55.

Astor P J, Adam MTP, Jähnig C, Seifert S (2013) The joy of winning and the frustration of losing: A psychophysiological analysis of emotions in first-price sealed-bid auctions. Journal of Neuroscience, Psychology, and Economics 6(1) 14-30.

Augenblick N (2015) The sunk-cost fallacy in penny auctions. The Review of Economic Studies 83(1) 58-86.

Bajari P, Hortaçsu A (2003) The Winner's Curse, Reserve Prices, and Endogenous Entry: Empirical Insights from eBay Auctions. Rand Journal of Economics 34(2) 329-355.

Bapna R., Goes P, Gupta A (2001) Insights and analyses of online auctions. Communications of the ACM 44(11): 42-50

Beil DR, Wein LM (2009) A pooling analysis of two simultaneous online auctions. Manufacturing \& Service Operations Management 11(1) 33-51.

Bertini M, Koenigsberg O (2014) When customers help set prices. Sloan Management Review 55(4): 57-66.

Biyalogorsky E, Koenigsberg O (2010) Ownership coordination in a channel: Incentives, returns, and negotiations. Quantitative Marketing and Economics 8(4) 461-490.

Boger DC, Shu SL (1998) Quantity-Split Strategy under Two-Contractor Competitive Procurement Environment. Naval Postgraduate School, NPS-54-88-008. 
Campbell MC (1999) Perceptions of Price Unfairness: Antecedents and Consequences. Journal of Marketing Research 36(2) 187-99.

Carpenter J (2007) Punishing free-riders: How group size affects mutual monitoring and the provision of public goods. Games and Economic Behavior 60(1) 31-51.

Carpenter J, Homes J, Matthews PH (2008) Charity auctions: A field experiment. Economic Journal 118(525) 92-113.

Carter CR, Kaufmann L (2007) The Impact of Electronic Reverse Auctions on Supplier Performance: The Mediating Role of Relationship Variables. Journal of Supply Chain Management 43 (1) 16-26.

Chandran S, Morwitz VG (2005) Effects of participative pricing on consumers' cognitions and actions: A goal theoretic perspective. Journal of Consumer Research 32(2): 249-259.

Chao Y, Fernandez J, Nahata B (2015) Pay-what-you-want pricing: Can it be profitable? Journal of Behavioral and Experimental Economics 57(August): 176-185.

Chen Y, Koenigsberg O, Zhang J (forthcoming) Pay-as-You-Wish Pricing. Marketing Science.

Chen-Ritzo C-H, Harrison TP, Kwasnica AM, Thomas DJ (2005) Better, Faster, Cheaper: An Experimental Analysis of a Multiattribute Reverse Auction Mechanism with Restricted Information Feedback, Management Science 51 (12) 1753-62.

Chernev A (2003) Reverse pricing and online price elicitation strategies in consumer choice. Journal of Consumer Psychology 13(1/2): 51-62.

Croson RTA, Marks MB (2000) Step returns in threshold public goods: A meta- and experimental analysis. Experimental Economics 2(3): 239-259.

Ding M, Eliashberg J, Huber J, Saini R (2005) Emotional Bidders: An Analytical and Experimental Examination of Consumers' Behavior in a Priceline-Like Reverse Auction, Management Science 51 (3) 352-64.

Eckel CC, Herberich DH, Meer J (2017) A field experiment on directed giving at a public university. Journal of Behavioral and Experimental Economics 66: 66-71. 
Edelman B, Ostrovsky M. Schwarz M (2007) Internet advertising and the generalized second-price auction: Selling billions of dollars worth of keywords. American Economic Review 97(1) 242-259.

Einav L, Farronato C, Levin JD, Sundaresan N (forthcoming) Auctions versus Posted Prices in Online Markets. Journal of Political Economy.

Elberse A, Bergsman J (2008) Radiohead: Music at your own price (A) Harvard Business School Publishing. case \# 9-508-110.

Elfenbein DW, McManus B (2010) A Greater Price for a Greater Good? Evidence that Consumers Pay More for Charity? Linked Products. American Economic Journal: Economic Policy 2(2) 28-60.

Elfenbein DW, Fisman R, McManus B (2012) Charity as a substitute for reputation: Evidence from an online marketplace. The Review of Economic Studies 79(4) 1441-1468.

Elyakime B, Laffont JJ, Loisel P, Vuong Q (1994) First-Price Sealed-Bid Auctions with Secret Reservation Prices. Annales D’Economie Et De Statistique 34: 115-141.

Engelbrecht-Wiggans R, Haruvy E, Katok E (2007) A Comparison of Buyer-Determined and Price-Based Multi-Attribute Mechanisms. Marketing Science 26 (5) 629-41.

Engers M, McManus B (2007) Charity auctions. International Economic Review 48(3) 953-994.

Evans KR, Beltramini RF (1987) A theoretical model of consumer negotiated pricing: An orientation perspective. Journal of Marketing 51(2) 58-73.

Fay S (2004) Partial-repeat-bidding in the name-your-own-price channel. Marketing Science 23(3): 407-418.

Fay S (2009) Competitive reasons for the Name-Your-Own-Price channel. Marketing Letters 20(3): 277-293.

Fehr E, Schmidt KM (1999) A Theory of Fairness, Competition, and Cooperation. Quarterly Journal of Economics 114(3) 817-868.

Försch S, Heise M, Skiera B (2017) The Impact of Floor Prices in Real-Time Online Display Advertising Auctions on Publisher's Profit. Working paper. 
Giving USA (2017) Total Charitable Donations Rise to New High of \$390.05 Billion, Posted on June 12, 2017 at 11:56 pm. Accessed Sept 25, 2017. https://givingusa.org/giving-usa-2017total-charitable-donations-rise-to-new-high-of-390-05-billion/

Gneezy A, Gneezy U, Riener G, Nelson LD (2012) Pay-What-You-Want, Identity, and SelfSignaling in Markets. Proceedings of the National Academy of Sciences 109 (19) 7236-40.

Gneezy A, Gneezy U, Nelson LD, Brown A (2010) Shared Social Responsibility: A Field Experiment in Pay-What-You-Want Pricing and Charitable Giving. Science 329: 325-7.

Gneezy U, Haruvy E, Roth AE (2003) Bargaining under a deadline: Evidence from the reverse ultimatum game. Games and Economic Behavior 45(2) 347-368.

Goeree JK, Maasland E, Onderstal S, Turner JL (2005) How (Not) to Raise Money. Journal of Political Economy 113(4) 897-926.

Greenleaf EA, Sinha AR (1996) Combining Buy-in Penalties with Commissions at Auction Houses. Management Science 42 (4) 529-40.

Greenleaf EA, Ma J, Wanhua Q, Rao AG, Sinha AR (2002) Note on 'Guarantees in Auctions: The Auction House as Negotiator and Managerial Decision Maker' Management Science 48 (12) $1640-44$.

Hann I-H, Terwiesch C (2003) Measuring the frictional costs of online transactions: The case of a name-your-own-price channel. Management Science 49(11): 1563-1579.

Haruvy E, Jap SD (2013) Differentiated Bidders and Bidding Behavior in Procurement Auctions. Journal of Marketing Research 50(2) 241-58.

Haruvy E, Katok E, Pavlov V (2016) Bargaining Process and Channel Efficiency, working paper.

Haruvy E, Popkowski Leszczyc PTL (2009) Bidder Motives in Cause Related Auctions, International Journal of Research in Marketing 26(4) 324-331.

Haruvy E, Popkowski Leszczyc PTL (2010a) Search and Choice in Online Auctions, Marketing Science 29(6) 1152-64.

Haruvy E, Popkowski Leszczyc PTL (2010b) The impact of online auction duration, Decision Analysis 7: 99-106.

Haruvy E, Popkowski Leszczyc PTL (2016) A Study of Bidding Behavior in Voluntary-Pay Philanthropic Auctions, working paper, University of Texas at Dallas. 
Haruvy E, Popkowski Leszczyc PTL, Ma Y (2014) Does Higher Transparency Lead to More Search in Online Auctions. Production and Operations Management 23(2) 197-209.

Häubl G, Popkowski Leszczyc PTL (2016) Bidding Frenzy: Speed of Competitor Reaction and Willingness to Pay in Auctions, working paper, University of Alberta

Haws KL, Bearden WO (2006) Dynamic Pricing and Consumer Fairness Perceptions. Journal of Consumer Research 33 (3) 304-11.

He Y, Popkowski Leszczyc PTL (2013) The Impact of Jump Bidding in Online Auctions, Marketing Letters 24(4) 387-97.

Herschlag M, Zwick R (2000) Internet auctions: Popular and professional literature review. Quarterly Journal of Electronic Commerce 1: 161-186.

Hinz O, Hann I-H, Spann M (2011) Price discrimination in e-commerce? An examination of dynamic pricing in name-your-own-price markets. MIS Quarterly 35(1): 81-98.

Hinz O, Spann M (2008) The impact of information diffusion on bidding behavior in secret reserve price auctions. Information Systems Research 19(3): 351-368.

Huck S, Rasul I (2011) Matched fundraising: Evidence from a natural field experiment. Journal of Public Economics 95(5): 351-362.

Isaac RM, Walker JM (1988) Group size effects in public goods provision: The voluntary contributions mechanism. Quarterly Journal of Economics 103(1) 179-199.

Jap SD, Haruvy E (2008) Interorganizational relationships and bidding behavior in industrial online reverse auctions. Journal of Marketing Research 45(5) 550-561.

Jap SD (2003) An Exploratory Study of the Introduction of Online Reverse Auctions. Journal of Marketing 67(3) 96-107.

Kagel J, Levin D (1986) The Winner's Curse and Public Information in Common Value Auctions. American Economic Review 76(5) 894-920.

Katkar R, Reiley DH (2006) Public Versus Secret Reserve Prices in eBay Auctions: Results from a Pokémon Field Experiment. Advances in Economic Analysis and Policy 6(2) Article 7.

Kim J-Y, Natter M, Spann M (2009) Pay what you want: A new participative pricing mechanism. Journal of Marketing 73(1): 44-58. 
Kim J-Y, Natter M, Spann M (2010) Kish: Where customers pay as they wish. Review of Marketing Science 8: Article 3.

Kim, J-Y, Brünner T, Skiera B, Natter M (2014) A comparison of different pay-per-bid auction formats. International Journal of Research in Marketing 31(4) 368-379.

Koschate-Fischer N, Stefan IV, Hoyer WD (2012) Willingness to Pay for Cause-Related Marketing: The Impact of Donation Amount and Moderating Effects. Journal of Marketing Research 49(6) 910-927.

Krämer F, Schmidt KM, Spann M, Stich L (2017) Delegating pricing power to customers: Pay What You Want or Name Your Own Price? Journal of Economic Behavior \& Organization 136 125-140

Ku G, Malhotra D, Murnighan JK (2005) Towards a competitive arousal model of decisionmaking: A study of auction fever in live and Internet auctions. Organizational Behavior and Human decision processes 96(2) 89-103.

Kunter M (2015) Exploring the Pay-What-You-Want payment motivation. Journal of Business Research 68(11): 2347-2357.

Lee K-C, Jalali A, Dasdan A (2013) Real Time Bid Optimization with Smooth Budget Delivery in Online Advertising. Proceedings of the 19th ACM Conference on Knowledge Discovery and Data Mining (KDD'13)

Lim B, Haruvy E, Popkowksi Leszczyc PTL (2016) On the value of added surcharge, working paper, UT-Dallas

Lucking-Reiley D, Spulber DF (2001) Business-to-business electronic commerce. Journal of Economic Perspectives 15 (1) 55- 68.

Lu Y, Gupta A, Ketter W, van Heck E (2013) Exploring Bidder Heterogeneity in Multichannel Sequential B2B Auctions. MIS Quarterly 40 (3) 645-662.

Mak V, Zwick R, Rao AR, Pattaratanakun JA (2015) Pay what you want as threshold public good provision. Organizational Behavior and Human Decision Processes 127:30-43.

Masclet D, Noussair C, Tucker S, Villeval MC (2003) Monetary and nonmonetary punishment in the voluntary contributions mechanism. The American Economic Review 93(1) 366-380 
Mayer A (1987) Military Procurements: Basic Principles and Recent Developments. George Washington Journal of International Law and Economics 21: 165-87.

Murnighan JK (2002) A very extreme case of the dollar auction. Journal of Management Education 26: 56-69.

Natter M, Kaufmann K (2015) Voluntary market payments: Underlying motives, success drivers and success potentials. Journal of Behavioral and Experimental Economics 57: 149-157.

Pilehvar A, Elmaghraby WJ, Gopal A (2016) Market Information and Bidder Heterogeneity in Secondary Market Online B2B Auctions. Management Science.

Pinker EJ, Seidmann A, Vakrat Y (2003) Managing online auctions: Current business and research issues. Management Science 49(11) 1454-1484.

Popkowski Leszczyc PTL, Häubl G (2010) To Bundle or Not to Bundle: Determinants of the Profitability of Multi-Item Auctions. Journal of Marketing 74(4) 110-24.

Platt BC, Price J, Tappen H (2013) The role of risk preferences in pay-to-bid auctions. Management Science 59(9): 2117-2134.

Popkowski Leszczyc PTL, Qiu C, Li S, Rothkopf MH (2015) Bidding Behaviors in Charity Auctions. Marketing Letters 26(1) 17-28.

Popkowski Leszczyc PTL, Rothkopf MH (2010) Charitable Motives and Bidding in Charity Auctions. Management Science 56(3) 399-413.

Regner T, Barria JA (2009) Do Consumers Pay Voluntarily? The Case of Online Music. Journal of Economic Behavior and Organization 71 (2) 395-406.

Riordan MH, Sappington DEM (1987) Awarding Monopoly Franchises. The American Economic Review 77 (3) 375-87.

Schmidt KM, Spann M, Zeithammer R (2015) Pay What You Want as a Marketing Strategy in Monopolistic and Competitive Markets. Management Science 61(6):1217-1236.

Shang J, Croson R (2009) A field experiment in charitable contribution: The impact of social information on the voluntary provision of public goods. The Economic Journal 119(540): 1422-1439. 
Shapiro D (2011) Profitability of the name-your-own-price channel in the case of risk-averse buyers. Marketing Science 30(2): 290-304.

Shapiro D, Zillante A (2009) Name your own price mechanisms: Revenue gain or drain? Journal of Economic Behavior and Organization 72(2): 725-737.

Spann M, Häubl G, Skiera B, Bernhardt M (2012) Bid-elicitation interfaces and bidding behavior in retail interactive pricing. Journal of Retailing 88(1):131-144.

Spann M, Skiera B, Schäfers B (2004) Measuring Individual Frictional Costs and Willingness-toPay via Name-Your-Own-Price Mechanisms. Journal of Interactive Marketing 18(4): 22-36.

Spann M, Stich L, Schmidt KM (forthcoming) Pay What You Want as a Pricing Model for Open Access Publishing? Communications of the ACM.

Spann M, Tellis GJ (2006) Does the internet promote better consumer decisions? The case of Name-Your-Own-Price auctions. Journal of Marketing 70(1):65-78.

Spann M, Zeithammer R, Häubl G (2010) Optimal reverse-pricing mechanisms. Marketing Science 29(6): 1058-1070.

Stafford MR, Stern B (2002) Consumer bidding behavior on Internet auction sites. International Journal of Electronic Commerce 7: 135-150.

Terwiesch C, Savin S, Hann I-H (2005) Online haggling and price-discrimination in a name-yourown-price channel. Management Science 51(3): 339-351.

Thomas M, Kyung EJ (2017) How Slider Scales Systematically Bias Willingness-to-Pay: Implicit Recalibration of Monetary Magnitudes. Working paper, Cornell University.

Tunca TI, Wu Q (2009) Multiple Sourcing and Procurement Process Selection with Bidding Events. Management Science 55(5) 763-80.

Varian HR, Harris C (2014) Market Design for Auction Markets. The VG Auction in Theory and Practice. American Economic Review. Papers \& Proceedings, 104(5) 442-445.

Vincent DR (1995) Bidding off the wall: Why reserve prices may be kept secret. Journal of Economic Theory 65(2) 575-584.

Wang T, Gal-Or E, Chatterjee R (2009) The name-your-own-price channel in the travel industry: An analytical exploration. Management Science 55(6): 968-979. 
Wathieu L, Brenner L, Carmon Z, Chattopadhyay A, Wertenbroch K, Drolet A, Gourville J, Muthukrishnan AV, Novemsky N, Ratner RK, Wu G (2002) Consumer control and empowerment: A primer. Marketing Letters 13(3) 297-305.

Zeithammer R (2006) Forward-looking bidding in online auctions, Journal of Marketing Research (43:3) 462-476.

Zeithammer R (2007a) Strategic Bid-Shading and Sequential Auctioning with Learning From Past Prices. Management Science (53:9) 1510-1519.

Zeithammer R (2007b) Optimal Selling in Dynamic Auctions: Adaptation versus Commitment. Marketing Science (26:6) 859-867.

Zeithammer R (2015) Optimal selling strategies when buyers name their own prices. Quantitative Marketing and Economics (13:2), 135-171.

Zeithammer R (2016) The Futility of Soft Floor Auctions. Working paper.

Zeithammer R, Adams C (2010) The sealed-bid abstraction in online auctions. Marketing Science 29(6) 964-987. 